\title{
Electrophysical Properties of Polymeric Nanocomposites Based on Barium Ferrites Modified by Copper Iodide
}

\author{
R. V. Mazurenko, S. L. Prokopenko, M. V. Abramov, G. M. Gunja,
} S. M. Makhno, and P. P. Gorbyk

Chuiko Institute of Surface Chemistry, N.A.S. of Ukraine, 17, General Naumov Str., UA-03164 Kyiv, Ukraine

Barium ferrites modified with copper iodide were synthesized by the solgel-autocombustion method. The sizes of barium-ferrite crystallites for all samples were of 20-50 $\mathrm{nm}$. The magnetic and electrophysical properties of $\mathrm{CuI} /$ ferrite-filled polychlorotrifluoroethylene (PCTFE) composites are investigated in the microwave range at ambient temperature. As shown, the introduction of $\mathrm{CuI} /$ ferrite composites into PCTFE leads to an increase of the values of the complex dielectric permittivity magnitude by $2-5$ times in comparison with the system containing the unmodified component.

Ферити барію, модифіковані йодидом міді, були синтезовані методою зольгель-автогоріння. Розміри кристалітів феритів барію для всіх зразків становили 20-50 нм. Магнетні й електрофізичні властивості композиційних матеріялів з поліхлортрифторетиленом (ПХТФЕ), наповнених $\mathrm{CuI} /$ ферит, досліджували в мікрохвильовому діяпазоні за температури навколишнього середовища. Показано, що введення композитів CuI/ферит у ПХТФЕ приводить до збільшення значень комплексної діелектричної проникности в 2-5 разів у порівнянні з системою із немодифікованим компонентом.

Key words: compositional material, disperse filler, interfacial interaction, barium hexaferrite, nanosize copper iodide.

Ключові слова: композиційний матеріял, дисперсні наповнювачі, міжфазна взаємодія, гексаферит барію, нанорозмірний йодид міді.

(Received 3 April, 2020)

\section{INTRODUCTION}

Electromagnetic field (EMF) shielding is an actual task of health 
protection, information security, electromagnetic compatibility and electromagnetic ecology of residential buildings [1]. The complex mechanism of propagation and absorption of electromagnetic radiation as well as the technological complexities of the synthesis of materials with predetermined electromagnetic properties in a wide range of frequencies are the reasons for the creation of new nanomaterials [2]. Since the ability of materials to absorb electromagnetic radiation is determined by their electrical and magnetic properties, which include specific electrical conductivity, dielectric and magnetic permeability, high dielectric and magnetic losses are important for such materials [3].

Therefore, to effective absorption of the electromagnetic wave, the creation of composite materials is required. The necessary absorption of composite materials can be obtained by changing the ratio of components with dielectric and magnetic properties. By using magnetic, dielectric, and conducting materials in the preparation of nanocomposite absorbing materials, it can be expected to obtain a powerful absorber with the contribution of various materials with various absorbing mechanism. The incorporation of conventional inorganics or non-magnetic materials and their using in the formulation of absorbing coatings has led to better absorption characteristics against to the individual components due to their interactions and synergetic effects [4]. The use of ferrite fillers $\left(\mathrm{MFe}_{2} \mathrm{O}_{4}\right.$, $M=\mathrm{Ni}-\mathrm{Zn}, \mathrm{Mg}-\mathrm{Zn}, \mathrm{Co}^{2+}, \mathrm{Ni}^{2+}, \mathrm{Fe}^{2+}, \mathrm{Zn}^{2+}, \mathrm{Cu}^{2+}$, etc.) in composite materials is promising due to their high value of saturation magnetization and magnetic losses including hysteresis loss and eddy current loss [5]. In addition, the hexaferrite barium $\left(\mathrm{BaFe}_{12} \mathrm{O}_{19}\right)$ features a moderate saturation magnetization, low toxicity, high mechanical hardness, excellent chemical stability [6, 7]. The dielectric permittivity in ferrites may arise from the nanoparticle modification with copper iodide. Copper iodide has attracted particular interest owing to several factors such as the high conductivity, negative spin orbit, diamagnetic behaviour, high and stable permittivity values [8]. Composites, in which ferrites are embedded into a polymer matrix, act as better EM absorbers than simple bulk ferrites. Furthermore, polymer matrix of PCTFE is flexibility, resistance to mechanical and chemical effects.

The aim of the research was to develop and synthesize the polymer-filled systems based on the PCTFE and surface-modified ferrites by copper iodide in order to study their electrophysical and magnetic properties as potential EMR-shielding materials.

\section{EXPERIMENTAL PART}

The $\mathrm{CuI} /$ barium ferrite nanocomposites were synthesized via the 
sol-gel-autocombustion method to create the newest nanomaterials that effectively interact with electromagnetic radiation. All the chemical reagents were pure grade and used without any purification.

The stoichiometric amounts of iron nitrate $\mathrm{Fe}\left(\mathrm{NO}_{3}\right)_{3} \cdot 9 \mathrm{H}_{2} \mathrm{O}$, barium nitrate $\mathrm{Ba}\left(\mathrm{NO}_{3}\right)_{2}$ were dissolved in distilled water. Then, appropriate amount of citric acid was added to nitrate solution with continuous stirring with a magnetic agitator. The molar ratio of nitrates to citric acid was $1: 1$. The $\mathrm{pH}$ was adjusted to 7.0 by $1.0 \mathrm{M}$ solution of $\mathrm{NH}_{4} \mathrm{OH}$. The reaction mixture then was stirred continuously at $100^{\circ} \mathrm{C}$ until partial solvent evaporation and transformation into a viscous gel. The gel was combusted in a self-propagation manner until all gel was completely burnt and converted to a powder form. Finally, after the reaction, high-dispersion powders (barium ferrite precursor-BFP) were calcined at $850^{\circ} \mathrm{C}$ in air for $5 \mathrm{~h}$ (see Eqs. (1)(4)) $[9,10]$ :

$$
\begin{gathered}
\mathrm{Gel} \rightarrow \mathrm{BaCO}_{3}+\gamma-\mathrm{Fe}_{2} \mathrm{O}_{3}, \\
\mathrm{BaCO}_{3}+\gamma-\mathrm{Fe}_{2} \mathrm{O}_{3} \rightarrow \mathrm{BaFe}_{2} \mathrm{O}_{4}+\mathrm{CO}_{2}, \\
\gamma-\mathrm{Fe}_{2} \mathrm{O}_{3} \rightarrow \alpha-\mathrm{Fe}_{2} \mathrm{O}_{3}, \\
\mathrm{BaFe}_{2} \mathrm{O}_{4}+5 \gamma-\mathrm{Fe}_{2} \mathrm{O}_{3} \rightarrow \mathrm{BaFe}_{12} \mathrm{O}_{19}
\end{gathered}
$$

Chemical modification of surface of the as-synthesized ferrite (BFP and $\mathrm{BaFe}_{12} \mathrm{O}_{19}$ ) by copper iodide was carried out via the coprecipitation of $\mathrm{CuI}$ from aqueous solutions of $\mathrm{CuSO}_{4}, \mathrm{KI}$ and $\mathrm{Na}_{2} \mathrm{~S}_{2} \mathrm{O}_{3}$ in the presence of barium ferrite, accordingly to the procedure described elsewhere [11] (the concentration of copper iodide on a surface of ferrite was 0.32 and 0.38 volume fractions):

$$
\begin{gathered}
2 \mathrm{CuSO}_{4} \cdot 5 \mathrm{H}_{2} \mathrm{O}+2 \mathrm{KI}+2 \mathrm{Na}_{2} \mathrm{~S}_{2} \mathrm{O}_{3} \cdot 5 \mathrm{H}_{2} \mathrm{O} \rightarrow \\
\rightarrow 2 \mathrm{CuI}+\mathrm{K}_{2} \mathrm{SO}_{4}+\mathrm{Na}_{2} \mathrm{~S}_{4} \mathrm{O}_{6}+20 \mathrm{H}_{2} \mathrm{O} .
\end{gathered}
$$

Polymer-filled composites were prepared by mechanical milling of the polychlorotrifluoroethylene (PCTFE) powder with modified ferrites (CuI/BFP, CuI/ $\mathrm{BaFe}_{12} \mathrm{O}_{19}$ ) until homogeneous mixture, which thereafter was compressed at the polymer-melt temperature of 513 $\mathrm{K}$ and a pressure of $2 \mathrm{MPa}$.

The real $\left(\varepsilon^{\prime}\right)$ and imaginary $\left(\varepsilon^{\prime \prime}\right)$ components of the complex permittivity of composites at microwave frequencies $(9 \mathrm{GHz})$ were measured using the interferometer (RFK 2-18, USSR) for measuring the phase difference and the standing wave meter (R2-60, USSR) by an electrodeless method [12]. The samples of the composites had a rectangular shape of $10 \times 23 \mathrm{~mm}$ with a thickness of 2 $\mathrm{mm}$. 
Crystalline structure was determined using the x-ray analysis (DRON-4-07, Lomo, USSR) in emission of the cobalt cathode with nickel filter in the Bragg-Brentano geometry. Crystallite sizes were determined from the width of the most intense line in $\mathrm{x}$-ray spectra according to the Scherrer equation [13]:

$$
D=k \lambda / \beta \cos \theta,
$$

where $k$ is a constant assumed to be equal to $0.9, \lambda$ is the $\operatorname{Co} K_{\alpha}$ wavelength $(0.1789 \mathrm{~nm}), \theta$ is the Bragg angle, and $\beta$ is the full width at half maximum of the x-ray diffraction peaks $[14,15]$.

Additional information about the microscopic structure of composites was obtained from transmission electron microscope (TEM) images (JEOL-1230).

Hysteresis curves of the magnetic moment for synthesized materials were recorded at room temperature by means of sample vibration magnetometer [16]. To exclude interaction between particles of the dry and highly dispersed particles under this investigation, samples were dispersed in paraffin at a volume concentration of $\cong 0.03$. For measurements, a cylindrical glass cuvette with an inner diameter of $2.5 \mathrm{~mm}$ and a height of $20 \mathrm{~mm}$ was used. The measurement setup and technique were described previously [17].
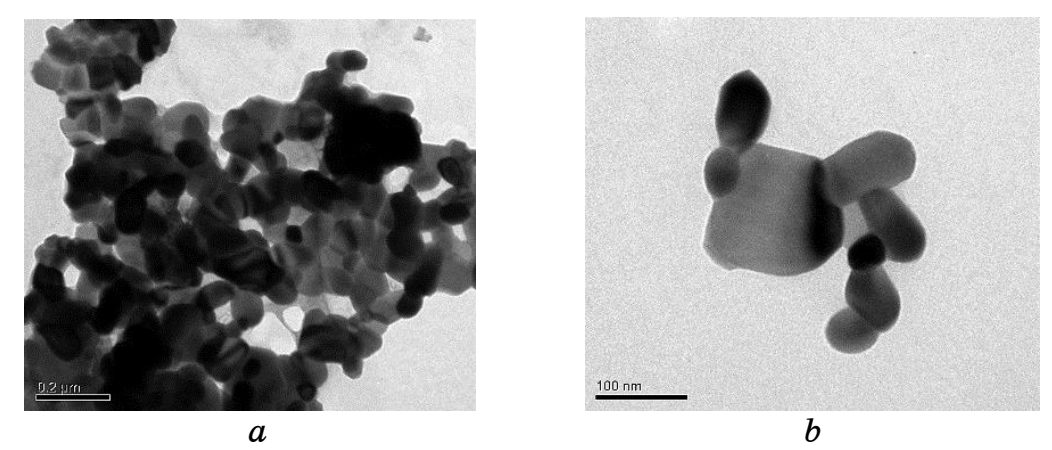

Fig. 1. TEM images of synthesized ferrite: $a, b-\mathrm{BaFe}_{12} \mathrm{O}_{19}$.

TABLE 1. Statistical characteristics of nanoparticle ensembles obtained for $\mathrm{BaFe}_{12} \mathrm{O}_{19}$.

\begin{tabular}{c|c|c|c|c|c}
\hline Sample & $D_{m}, \mathrm{~nm}$ & $\sigma, \mathrm{nm}$ & $(\ln D)_{m}$ & $\sigma_{\ln D}$ & $N$ \\
\hline $\mathrm{BaFe}_{12} \mathrm{O}_{19}$ & 67.16 & 46.1832 & 4.01 & 0.6671 & 132 \\
\hline
\end{tabular}

Note: $D_{m}$ - the mean diameter; $\sigma$-mean root square deviation of particle diameter; $(\ln D)_{m}$ - the mean logarithm diameter; $\sigma_{\ln D}$-mean root square deviation of logarithm diameter; $N$-number of particles in the ensemble. 


\section{RESULTS AND DISCUSSION}

Transmission electron microscopy was used to determine the size and shape of the as-synthesized nanoparticles of barium ferrite (Fig. 1). As shown in Fig. 1, $a, b$, the average size nanoparticles of barium ferrite are of $20-50 \mathrm{~nm}$. All the TEM images show moderately agglomerated and individual particles.

Statistical analysis of initial ferrites was performed by random sampling of more than 50 particles using the TEM image. The mean diameters of synthesized nanoparticles, their mean root square deviation, and the number of particles in the studied ensembles of the synthesized ferrites derivatives were calculated (Table 1).

The probability density curve of the lognormal distribution of $\mathrm{BaFe}_{12} \mathrm{O}_{19}$ nanoparticles in diameter is a better approximation to the experimental histogram of relative frequencies than the probability density curve of the normal distribution of $\mathrm{BaFe}_{12} \mathrm{O}_{19}$ nanoparticles in diameter (Fig. 2).

Lognormal distribution of nanoparticles is realized with a parallel mechanism of particle growth: atom-atom, dimer-dimer, tetramertetramer, octamer-octamer, etc. In this case, the number of atoms in the particle is described by the sum of geometric progression. In a random process and parallel growth mechanism, the nanoparticles are lognormally distributed [18].

Crystalline structure of the as-synthesized ferrites and their $\mathrm{CuI}$ modified derivatives were studied with x-ray analysis (Fig. 3). Diffractograms of BPS (curve 1) indicate the samples had cubic $\mathrm{Fe}_{3} \mathrm{O}_{4}$ phase (JCPDS 88-315) and $\mathrm{BaCO}_{3}$ orthorhombic phase (JCPDS 712394). The formation of the $\mathrm{BaFe}_{12} \mathrm{O}_{19}$ phase (JCPDS 84-0757) was observed in the case of annealed samples (curve 3). Diffraction patterns of ferrites modified by copper iodide (curve 2,4 ), contains all reflections corresponding to ferrites and planes that refer to the presence of the copper iodide cubic phase (JCPDS 83-1105) and hexagonal phase $\mathrm{CuI}$. Additional diffraction peak at $2 \Theta=38.51^{\circ}$ observed in Fig. 3 was identified as hexagonal phase of $\mathrm{Fe}_{2} \mathrm{O}_{3}$ (JCPDS 33-664), which probably arises due to the calcination of the ferrite sample in air at high temperature.

An average crystallite size of copper iodide for all samples is of about $25 \mathrm{~nm}$. The crystallites' size of the synthesized BFP and $\mathrm{BaFe}_{12} \mathrm{O}_{19}$ samples is $\cong 50 \mathrm{~nm}$.

The results of thermogravimetric analysis of the synthesized ferrite samples are presented in Fig. 4. The process of thermal decomposition of samples consists of three stages. The first stage is observed in the temperature range from 50 to $200^{\circ} \mathrm{C}$ with a slight weight loss (up to $2 \%$ ), which may correspond to the evaporation of adsorbed water (curve 1). The second stage, from 200 to $800^{\circ} \mathrm{C}$, re- 


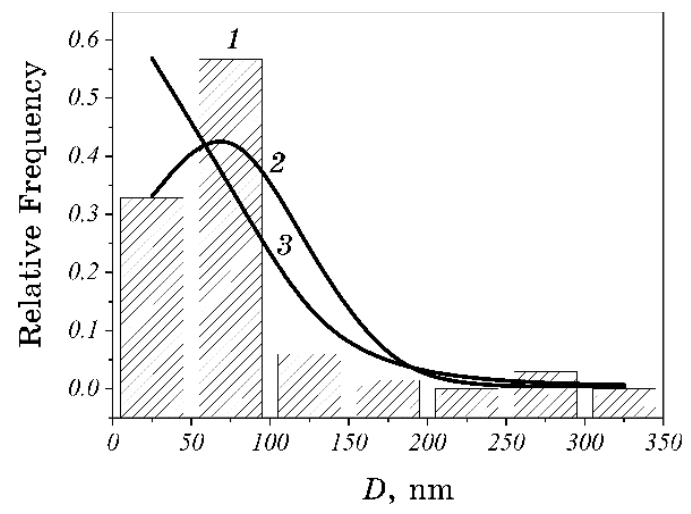

Fig. 2. Experimental histogram of relative frequencies (1), the probability density of the lognormal (2) and normal (3) distributions of $\mathrm{BaFe}_{12} \mathrm{O}_{19}$ nanoparticle diameters.
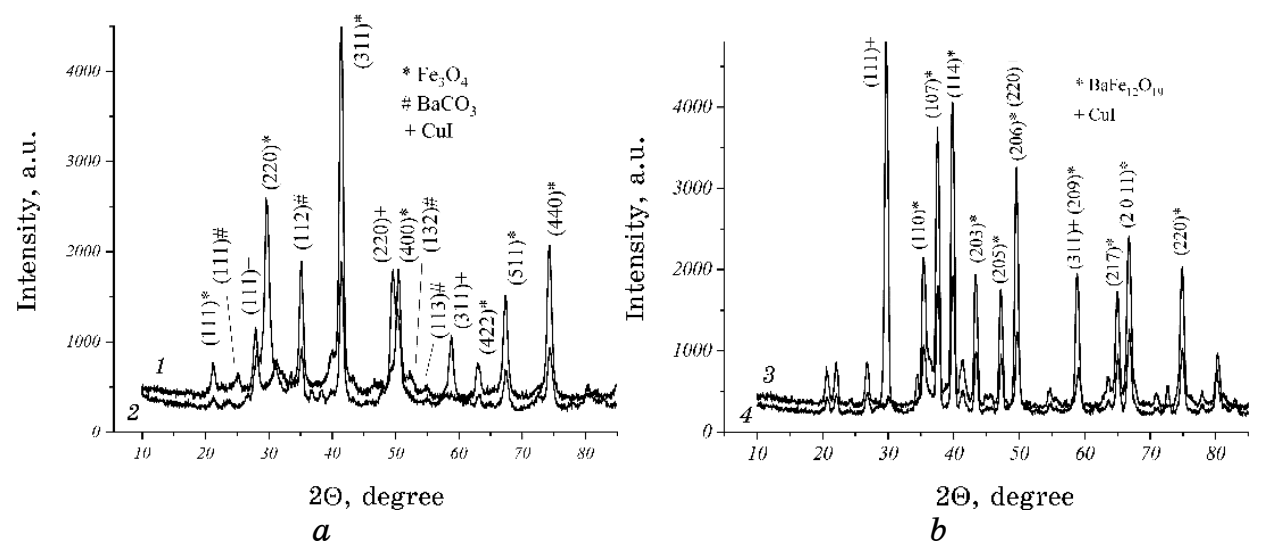

Fig. 3. X-ray diffraction patterns of nanocomposites: 1-BFP; 2$0.32 \mathrm{CuI} / \mathrm{BFP} ; 3-\mathrm{BaFe}_{12} \mathrm{O}_{19} ; 4-0.32 \mathrm{CuI} / \mathrm{BaFe}_{12} \mathrm{O}_{19}$.

lates to the decomposition of $\mathrm{BaCO}_{3}$ with the formation of monoferrite first and subsequently barium hexaferrite [19]. Mass loss at temperatures above $800^{\circ} \mathrm{C}$ is not observed. This indicates the completion of thermal decomposition and the final formation of the $\mathrm{BaFe}_{12} \mathrm{O}_{19}$ phase.

Optimum concentrations of the copper iodide $(0.32<\phi<0.38)$, at which the maximum values of the complex permittivity and electrical conductivity in $\mathrm{CuI} / \mathrm{BFP}$ and $\mathrm{CuI} / \mathrm{BaFe}_{12} \mathrm{O}_{19}$ systems, were determined experimentally.

Under introduction of $\mathrm{CuI} / \mathrm{BFP}$ and $\mathrm{CuI} / \mathrm{BaFe}_{12} \mathrm{O}_{19}$ into the PCTFE, the values of $\varepsilon^{\prime}, \varepsilon^{\prime \prime}$ and $\sigma$ depend nonlinearly on the volume 
content of copper iodide. The observed concentration dependences are probably related to change in sizes of the copper-iodide particles or structure of their clusters on the surface of ferrite.

Chemical modification of surface of the ferrite by copper iodide leads to an increase in $\varepsilon^{\prime}$ and $\varepsilon^{\prime \prime}$ in the microwave range of polymer composites (CuI/BFP-PCTFE, $\left.\mathrm{CuI} / \mathrm{BaFe}_{12} \mathrm{O}_{19}-\mathrm{PCTFE}\right)$ with respect to the system, which does not contain modified components (CuIPCTFE) (Fig. 5). This effect is because ferrite particles modified by copper iodide are forming more branched clusters in polymer matrix at lower concentrations, as well as the influence of the polymer

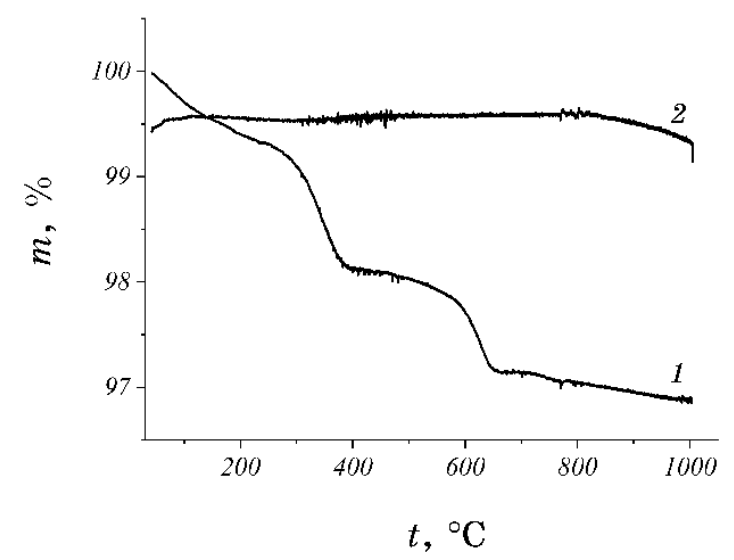

Fig. 4. Derivatives of synthesized ferrites: $1-\mathrm{BFP} ; 2-\mathrm{BaFe}_{12} \mathrm{O}_{19}$.
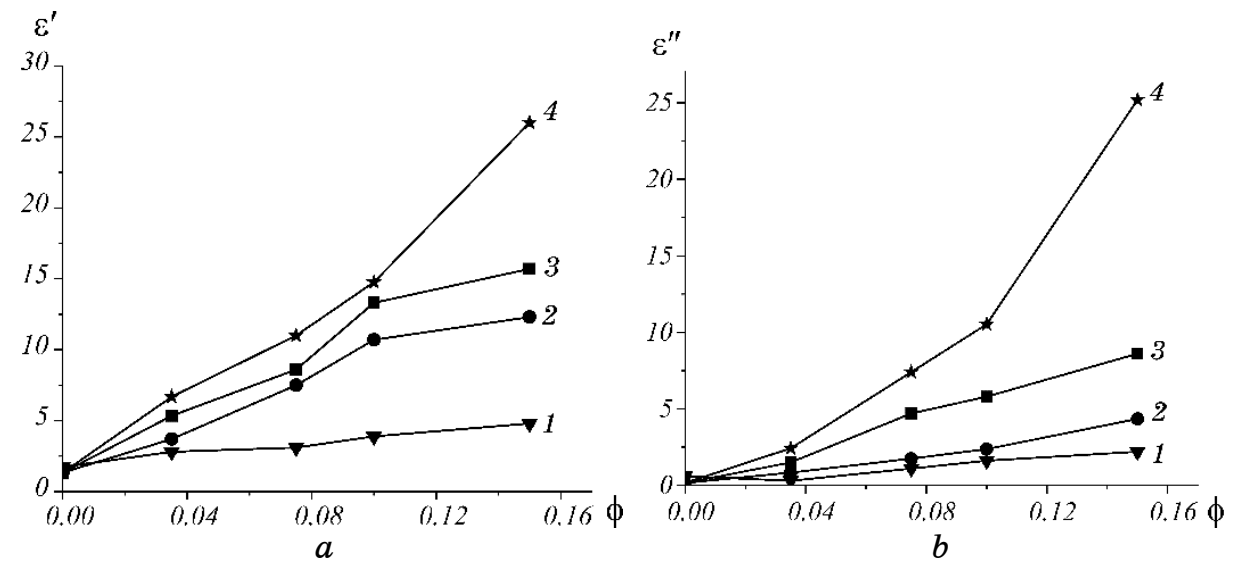

Fig. 5. Dependences of the $\varepsilon^{\prime}(a)$ and $\varepsilon^{\prime \prime}(b)$ at $9 \mathrm{GHz}$ of the copper iodide volume fractions $(\phi)$ in polymer composite systems: 1-CuI-PCTFE; 20.32CuI $/ \mathrm{BaFe}_{12} \mathrm{O}_{19}-\mathrm{PCTFE}$; $3-0.32 \mathrm{CuI} / \mathrm{BFP}-\mathrm{PCTFE} ; 4-0.38 \mathrm{CuI} / \mathrm{BaFe}_{12} \mathrm{O}_{19}-$ PCTFE. 

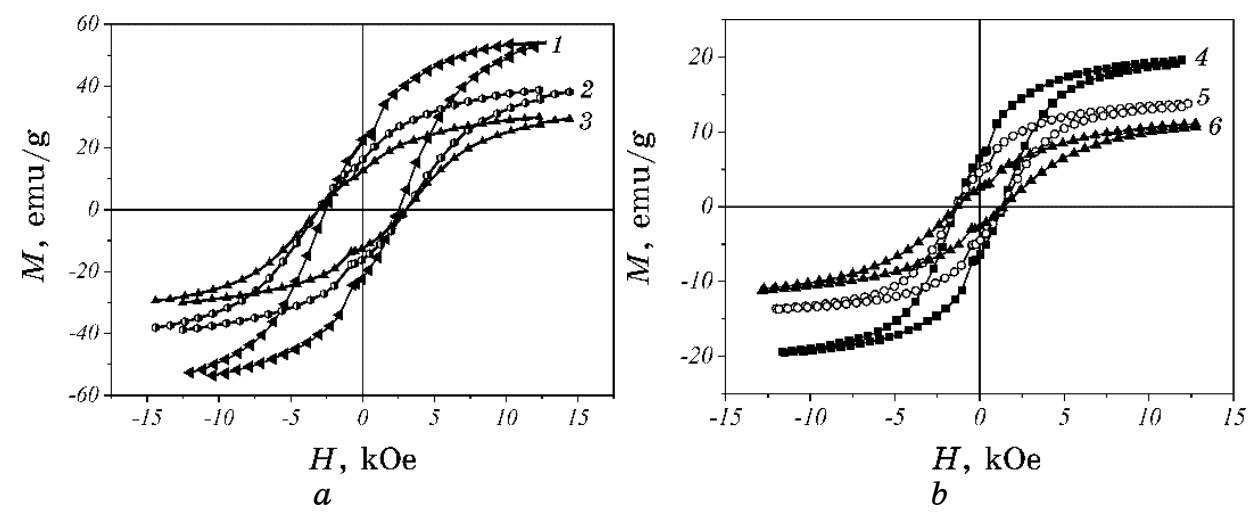

Fig. 6. Hysteresis loops for synthesized ferrites' samples and modified one with different content of the copper iodide: 1- $\mathrm{BaFe}_{12} \mathrm{O}_{19}, 2-$ $0.32 \mathrm{CuI} / \mathrm{BaFe}_{12} \mathrm{O}_{19} ; 3-0.38 \mathrm{CuI} / \mathrm{BaFe}_{12} \mathrm{O}_{19} ; 4-\mathrm{BFP} ; 5-0.32 \mathrm{CuI} / \mathrm{BFP} ; 6-$ $0.38 \mathrm{CuI} / \mathrm{BFP}$.

boundary layers on the electrophysical properties of the obtained composites.

In the case of $0.32 \mathrm{CuI} / \mathrm{BaFe}_{12} \mathrm{O}_{19}$ composites, the value of the complex permittivity and electrical conductivity is lower than for a system with $0.32 \mathrm{CuI} / \mathrm{BFP}-\mathrm{PCTFE}$. Upon annealing of BFP, the formation of an ordered structure of barium hexaferrite occurs and, as a result, the defective structure of the ferrite surface decreases. This leads to an increase in the size of crystallites of copper iodide on the surface of the $\mathrm{BaFe}_{12} \mathrm{O}_{19}$ and, possibly, to an increase in the size of agglomerates of copper iodide during the modification of barium ferrite.

The magnetization hysteresis loops recorded at room temperature for synthesized ferrites and their modified derivatives are shown in Fig. 6.

With an increase of the $\mathrm{CuI}$ concentration, the specific saturation magnetization of $\mathrm{CuI} / \mathrm{BFP}$ and $\mathrm{CuI} / \mathrm{BaFe}_{12} \mathrm{O}_{19}$ samples decreases monotonically from 21.4 to $10.4 \mathrm{G} \cdot \mathrm{cm}^{3} / \mathrm{g}$ and from 54.6 to $29.5 \mathrm{G} \cdot \mathrm{cm}^{3} / \mathrm{g}$, respectively (Fig. 6). At the same time, an increase in coercive force of $\mathrm{CuI} / \mathrm{BaFe}_{12} \mathrm{O}_{19}$ has monotonic character, whereas the same for $\mathrm{CuI} / \mathrm{BFP}$ is nonmonotonic. Magnetic characteristics for all the samples are listed in Table 2. Obtained specific saturation magnetization of $\mathrm{BaFe}_{12} \mathrm{O}_{19}$ is $54.6 \mathrm{G} \cdot \mathrm{cm}^{3} / \mathrm{g}$, which is significantly lower than the calculated one for a bulk ferrite particle $(67.7$ $\mathrm{G} \cdot \mathrm{cm}^{3} / \mathrm{g}$ ). A decrease in the magnetization of $\mathrm{BaFe}_{12} \mathrm{O}_{19}$ particles with a decrease in their size is probably caused by incomplete coordination of atoms on the particle surface, which leads to a noncollinearity spin configuration and causes disorientation of the surface 
TABLE 2. Magnetic characteristics of synthesized ferrites and their derivatives.

\begin{tabular}{c|c|c|c|c|c|c}
\hline Sample composition & $\begin{array}{c}H_{c}, \\
\mathrm{Oe}\end{array}$ & $\begin{array}{c}M_{10 \mathrm{kOe}}, \\
\mathrm{G} \cdot \mathrm{cm}^{3} / \mathrm{g}\end{array}$ & $\begin{array}{c}M_{s}, \\
\mathrm{G} \cdot \mathrm{cm}^{3} / \mathrm{g}\end{array}$ & $\begin{array}{c}M_{r}, \\
\mathrm{G} \cdot \mathrm{cm}^{3} / \mathrm{g}\end{array}$ & $M_{r} / M_{s}$ & $C_{v}(\mathrm{CuI})$ \\
\hline $\mathrm{BaFe}_{12} \mathrm{O}_{19}$ & 2.54 & 53.1 & 54.6 & 22.3 & 0.40 & 0 \\
$0.32 \mathrm{CuI} / \mathrm{BaFe}_{12} \mathrm{O}_{19}$ & 3.05 & 37.6 & 38.6 & 15.9 & 0.41 & 0.29 \\
$0.38 \mathrm{CuI} / \mathrm{BaFe}_{12} \mathrm{O}_{19}$ & 3.04 & 28.7 & 29.5 & 12.1 & 0.40 & 0.43 \\
$\mathrm{BFP}$ & 1.24 & 26.7 & 21.4 & 11.3 & 0.52 & 0 \\
$0.32 \mathrm{CuI} / \mathrm{BFP}$ & 1.83 & 14.8 & 15.2 & 5.22 & 0.34 & 0.29 \\
$0.38 \mathrm{CuI} / \mathrm{BFP}$ & 1.63 & 10.1 & 10.4 & 2.48 & 0.23 & 0.41 \\
\hline
\end{tabular}

Note: $H_{c}$-coercive force; $M_{10 \mathrm{kOe}}$-specific magnetization; $M_{s}$-specific saturation magnetization; $M_{r}$-residual specific magnetization; $M_{r} / M_{s}$-relative residual specific magnetization; *-with $\alpha-\mathrm{Fe}_{2} \mathrm{O}_{3}$ on the surface of ferrite particles [22].

spin tilt and, due to thermal fluctuations of magnetic moments, significantly reduces the total magnetic moment for a given magnetic field [20, 21].

With an increase in the CuI concentration of the ferrite surface, the values of the residual magnetization decrease and the coercive force of the composites increases. It is known that the experimental values of the coercive force $\left(H_{c}\right)$ of ensembles of monodisperse single-domain magnetite particles with a diameter of $30-50 \mathrm{~nm}$ are of 350-450 Oe. The critical diameter of a single-domain magnetite particle is of $\cong 50 \mathrm{~nm}$. The theoretical value of $H_{c}$ of a singledomain particle $\mathrm{Fe}_{3} \mathrm{O}_{4}$ is $2\left|K_{1}\right| / M_{s} \cong 454$ Oe, where $K_{1}$ is the first anisotropy constant $\left(1.07 \cdot 10^{5} \mathrm{erg} \cdot \mathrm{cm}^{-3}\right), 4 \pi M_{s}$ is the saturation induction of $6000 \mathrm{Gs}$ at $300 \mathrm{~K}$. The theoretical value of the $H_{c}$ ensemble of statistically oriented single domain $\mathrm{BaFe}_{12} \mathrm{O}_{19}$ crystallites is $0.96\left|K_{1}\right| / M_{s} \cong 8 \mathrm{kOe}$, where $K_{1}=3.3 \cdot 10^{6} \mathrm{erg} \cdot \mathrm{cm}^{-3}, 4 \pi M_{s}=4775 \mathrm{Gs}$ at $300 \mathrm{~K}$. Samples of $\mathrm{BaFe}_{12} \mathrm{O}_{19}$ have higher $H_{c}$ in comparison with samples barium-ferrite precursor, which includes $\mathrm{Fe}_{3} \mathrm{O}_{4}$.

\section{CONCLUSIONS}

Barium hexaferrite with average nanoparticles size of about 20-50 $\mathrm{nm}$ was synthesized by means of the sol-gel-autocombustion process.

The values of $\varepsilon^{\prime}, \varepsilon^{\prime \prime}$ in the microwave range nonlinearly depend on the concentration of $\mathrm{CuI}$ for modified ferrites $\left(\mathrm{BaFe}_{12} \mathrm{O}_{19}, \mathrm{BFP}\right)$ and reaches a maximum value at 0.38 volume fractions.

An introduction of the $\mathrm{CuI} / \mathrm{BaFe}_{12} \mathrm{O}_{19}$ and $\mathrm{CuI} / \mathrm{BFP}$ in polychlorotrifluoroethylene leads to an increase in the electrophysical parameters in all concentration range at room temperature. 


\section{REFERENCES}

1. S. Cucurachi, W. L. M. Tamis, M. G. Vijver, W. J. G. M. Peijnenburg, J. F. B. Bolte, and G. R. de Snoo, Environment International, 51: 116 (2013); https://doi.org/10.1016/j.envint.2012.10.009

2. M. Green and X. Chen, Journal of Materiomics, 5, Iss. 4: 503 (2019); https://doi.org/10.1016/j.jmat.2019.07.003

3. Electromagnetic Fields and Waves (Eds. Kim Ho Yeap and K. Hirasawa); https://doi.org/10.5772/intechopen.77420

4. V.Shukla, Nanoscale Adv., 1: 1640 (2019); https://doi.org/10.1039/C9NA00108E

5. C. Hu, Z. Gao, and X. Yang, Journal of Magnetism and Magnetic Materials, 320: L70 (2008); https://doi.org/10.1016/j.jmmm.2007.12.006

6. M. H. Makled, T. Matsui, H. Tsuda, H. Mabuchi, M. K. El-Mansy, and K. Morii, Journal of Materials Processing Technology, 160: 229 (2005); https://doi.org/10.1016/j.jmatprotec.2004.06.013

7. G. Mu, N. Chen, X. Pan, H. Shen, and M. Gu, Materials Letters, 62: 840 (2008); http://dx.doi.org/10.1016/j.matlet.2007.06.074

8. F. Tavakoli, M. Salavati-Niasari, D. Ghanbari, K. Saberyan, and M. Hosseinpour-Mashkani, Materials Research Bulletin 49: 14 (2014); https://doi.org/10.1016/j.materresbull.2013.08.037

9. G. Mu, X. Pan, H. Shen and M. Gu, Materials Science and Engineering A, 445: 563 (2007); https://doi.org/10.1016/j.msea.2006.09.078

10. T. Zhao, W. Jin, X. Ji, H. Yan, Y. Jiang, Y. Dong, Y. Yang, A. Dang, H. Li, T. Li, S. Shang, and Z. Zhou, Journal of Alloys and Compounds, 712: 59 (2017); https://doi.org/10.1016/j.jallcom.2017.04.070

11. Rukovodstvo po Neorganicheskomu Sintezu (Ed. G. Brauer) (Moscow: Mir: 1985) (Russian translation); https://doi.org/10.1002/maco.19620131132

12. L. N. Ganiuk, V. D. Ignatkov, S. N. Makhno, and P. N. Soroka, Ukr. Phys. Zhurn., 40, No. 6: 627 (1995) (in Russian).

13. A. Guinier, Rentgenografiya Kristallov (Moscow: Gos. Izd-vo Fiz.-Mat. Lit.: 1995) (Russian translation).

14. C. Hammond, The Basics of Crystallography and Diffraction (Oxford: Oxford University Press: 1997).

15. P. Scardi, M. Leoni, and R. Delhez, J. Appl. Crystallogr., 37: 381 (2004); https://doi.org/10.1107/S0021889804004583

16. S. Foner, Rev. Sci. Instrum., 30: 548 (1959); https://doi.org/10.1063/1.1716679

17. A. L. Petranovska, N. V. Abramov, S. P. Turanska, P. P. Gorbyk, A. N. Kaminskiy, and N.V. Kusyak, J. Nanostruct. Chem., 5: 275 (2015); https://doi.org/10.1007/s40097-015-0159-9

18. A. Yu. Olenin, Nanotechnologies in Russia, 7: 238 (2012); https://doi.org/10.1134/S1995078012030123

19. S. Kumar, S. Supriya, and M. Kar, Materials Today: Proceedings, 4, Iss. 4, Part E: 5517 (2017); https://doi.org/10.1016/j.matpr.2017.06.007

20. M. Drofenik, I. Ban, G. Ferk, D. Makovec, A. Znidarsic, Z. Jaglicic, and D. Lisjak, J.Am.Ceram.Soc., 93: 1602 (2010); https://doi.org/10.1111/j.1551-2916.2010.03620.x

21. R. H. Kodama, A. E. Berkowitz, E. J. McNiff, Jr., and S. Foner, Phys. Rev. Lett., 77: 394 (1996); https://doi.org/10.1103/PhysRevLett.77.394

22. P. Sahoo, Probability and Mathematical Statistics (Louisville, KY, USA: Department of Mathematics, University of Louisville: 2013). 